\title{
PENGGUNAAN REAKTOR BIOFILTER UNTUK MENINGKATKAN KUALITAS LIMBAH CAIR DI RSUD Dr. SOETOMO SURABAYA
}

\author{
Suhariono *) dan Pungut $\mathbf{A S}^{\star \star}$ ) \\ Program Studi Teknik Lingkungan Fakultas Teknik Sipil dan Perencanaan \\ Universitas PGRI Adi Buana Surabaya \\ e-mail : harionow@gmail.com dan pung.link@gmail.com
}

\begin{abstract}
ABSTRAK
Limbah cair yang berasal dari rumah sakit merupakan salah satu sumber pencemaran air. $\mathrm{Hal}$ ini disebabkan karena limbah cair rumah sakit mengandung senyawa organik yang cukup tinggi dan mengandung senyawa kimia lain serta mikro-organisme patogen yang dapat menyebabkan penyakit terhadap masyarakat di sekitarnya. Limbah cair rumah sakit mengandung zat pencemar organik maupun anorgnik seperti $C O D$ dan BOD, zat padat tersuspensi yaitu TSS dan nutrient seperti Phosfat $\left(\mathrm{PO}_{4}\right)$. Tujuan dari penelitian ini adalah untuk mengetahui efisiensi penurunan kandungan TSS, BOD, COD, $P O_{4}$ pada limbah cair IPAL Sentral RSUD Dr. Soetomo Surabaya dengan menggunakan reaktor biofilter yang membandingkan 3 buah reaktor. Reaktor pertama menggunakan media pasir silika (diameter 2-5 $\mathrm{mm}$ ) dan kerikil (diameter 2-3 cm), reaktor kedua menggunakan media bioball (diameter $4 \mathrm{~cm}$ ) dan reaktor ketiga menggunakan gabungan media pasir silika-kerikil dan media bioball. Proses penelitian ini meliputi proses pembiakan bakteri dengan merendam di IPAL selama 15 hari, dilanjutkan dengan aklimatisasi selama 2 hari dengan arah aliran up flow dan debit aliran rata-rata pada reaktor I adalah 1,06 ml/dt, reaktor II adalah 0,83 $\mathrm{ml} / \mathrm{dt}$ dan reactor III adalah $0,85 \mathrm{ml} / \mathrm{dt}$. Hasil penelitian diperoleh bahwa reaktor biofilter I menghasilkan efisiensi penurunan kandungan TSS sebesar $57 \%$, efisiensi penurunan kandungan $B O D_{5}$ sebesar $71 \%$, efisiensi penurunan kandungan $C O D$ sebesar $67 \%$ dan efisiensi penurunan kandungan Phospat $\left(\mathrm{PO}_{4}\right)$ sebesar $12 \%$. Reaktor biofilter ke II menghasilkan efisiensi penurunan kandungan TSS sebesar $46 \%$, efisiensi penurunan kandungan $B O D_{5}$ sebesar $62 \%$, efisiensi penurunkan kandungan COD sebesar $55 \%$ dan efisiensi penurunan kandungan Phospat $\left(\mathrm{PO}_{4}\right)$ sebesar $12 \%$. Untuk reaktor biofilter ke III menghasilkan efisiensi penurunan kandungan TSS sebesar $74 \%$, efisiensi penurunan kandungan $B O D_{5}$ sebesar $73 \%$, efisiensi penurunan kandungan $C O D$ sebesar $70 \%$ dan efisiensi penurunan kandungan Phospat $\left(\mathrm{PO}_{4}\right)$ sebesar $14 \%$. Dari hasil penelitian yang dilakukan, maka ketiga reaktor yang diteliti mampu menurunkan parameter TSS, BOD, COD dan $P_{4}$, tetapi nilai tersebut sebagian masih di atas baku mutu berdasarkan Keputusan Gubernur Jawa Timur No. 72 Tahun 2013.
\end{abstract}

Kata Kunci : IPAL Biofilter, limbah cair rumah sakit, kandungan TSS, $B O D_{5}, C O D$ dan $P O_{4}$, Media Pasir, Media Kerikil dan Media Bioball

\section{PENDAHULUAN}

Rumah Sakit adalah institusi pelayanan kesehatan yang menyelenggarakan pelayanan kesehatan perorangan secara paripurna yang menyediakan pelayanan rawat inap, rawat jalan, dan gawat darurat, (Undang-Undang RI No 44 Tahun 2009). Oleh karena itu rumah sakit mempunyai kaitan yang erat dengan keberadaan kumpulan manusia atau masyarakat tersebut. Di masa lalu, suatu rumah sakit dibangun di suatu wilayah yang jaraknya cukup jauh dari daerah pemukiman, dan biasanya dekat dengan sungai dengan pertimbangan agar pengelolaan limbah cair tidak berdampak negatif terhadap penduduk, atau bila ada dampak negatif maka dampak tersebut dapat diperkecil. Rumah Sakit Umum Daerah (RSUD) Dr. Soetomo Surabaya merupakan salah satu rumah sakit milik pemerintah provinsi yang telah memiliki Instalasi Pengolahan Air Limbah (IPAL). Debit air limbah yang dihasilkan sebesar $\pm 500 \mathrm{~m}^{3} / \mathrm{hr}$, yang dihasilkan dari kegiatan klinis dan domestik, (RKL-RPL RSUD Dr Soetomo, 2014). RSUD Dr. Soetomo Surabaya telah memiliki instalasi pengolahan air limbah (IPAL) Sentral dengan metode pengolahan berupa activated sludge (lumpur aktif). Berdasarkan data sekunder dari hasil pemeriksaan laboratorium yang dilakukan oleh BLH Provinsi Jawa Timur pada Bulan September 2014 bahwa limbah cair di lokasi inlet IPAL Sentral RSUD

Dr. Soetomo untuk parameter TSS sebesar 109 $\mathrm{mg} / \mathrm{l}, \mathrm{BOD}_{5}$ sebesar $154 \mathrm{mg} / \mathrm{l}$, COD sebesar $376 \mathrm{mg} / \mathrm{l}$, dan $\mathrm{PO}_{4}$ sebesar 1,92 $\mathrm{mg} / \mathrm{l}$, bahwa beberapa parameter tersebut belum memenuhi baku mutu limbah cair bagi kegiatan rumah sakit berdasarkan Peraturan Gubernur Jawa Timur No. 72 Tahun 2013. Berdasarkan latar belakang 
tersebut, maka peneliti tertarik untuk melakukan penelitian tentang penggunaan reaktor biofilter untuk meningkatkan kualitas limbah cair di rumah sakit tersebut.

Prinsip dasar pengolahan air limbah adalah untuk menghilangkan bahkan mengurangi kontaminan yang terdapat dalam air limbah, (Mara, 1978). Menurut Metcalf \& Eddy (1991), bahwa metode pengolahan air limbah tersebut dapat menghasilkan tingkat penurunan yang memadai untuk berbagai kategori polutan seperti BOD, COD, TSS, N, P dan organism pathogen. Penelitian ini menggunakan limbah cair yang berasal dari RSUD Dr. Soetomo yang di olah dengan teknologi biofilter, dimana biofilter merupakan suatu istilah dari reaktor yang dikembangkan dengan prinsip mikroba tumbuh dan berkembang menempel pada suatu media filter dan membentuk biofilm (attached growth), (Siti Komariyah \& Sugito, 2011). Pengolahan ini adalah pengolahan yang sangat mudah dan sangat murah dari segi operasional. Biofilter dapat digunakan untuk air limbah dengan beban BOD yang cukup besar dan dapat menghilangkan padatan tersuspensi (SS) dengan baik. (Nusa Idaman said, 2005). Sumber limbah cair yang ada di RSUD Dr. Soetomo antara lain berasal dari unit pelayanan medis yang meliputi : rawat Inap, rawat jalan, rawat darurat, rawat intensif, haemodialisa, bedah sentral, rawat isolasi, unit penunjang pelayanan medis dan laboratorium yang meliputi : radiologi, farmasi, sterilisasi, kamar jenazah, unit penunjang pelayanan non medis meliputi : logistik, laundry, rekam medis, fasilitas umum yaitu masjid / Musholla dan Kantin, kesekretariatan / administrasi dan dapur gizi, (Lidya Maharani, 2005).

Teknologi pengolahan limbah cair dengan biofilter merupakan teknologi pengolahan secara biologis dengan menggunakan biakan melekat (attached culture), yaitu proses pengolahan limbah cair dimana mikroorganisme yang digunakan dibiakkan pada suatu media, sehingga mikroorganisme tersebut tumbuh dan berkembang pada suatu media filter dan membentuk lapisan koloni biofilm dengan suplai udara, (Sugito, 2009). Keberhasilan pengolahan limbah cair dengan teknologi biofilter sangat tergantung pada lajunya pertumbuhan mikrobiologis. Untuk pertumbuhan mikrobiologis membutuhkan media (antara lain digunakan gravel/kerikil), oleh karena itu pada sistem biofilter digunakan media gravel atau kerikil (ukuran 1" dan 2,5") dimana mikroba akan tumbuh dan membentuk lapisan tipis pada permukaan media tersebut, (Lemlit ITS, 1998).

Menurut Said (1999), pengolahan limbah cair (biofilter) menggunakan media pasir dengan sistem aliran up flow mempunyai keunggulan antara lain tidak memerlukan bahan kimia, sehingga biaya operasinya murah, dapat menghilangkan zat besi, mangan, dan warna serta kekeruhan, dapat menghilangkan amonia dan polutan oganik, karena proses penyaringan berjalan secara fisik dan biokimia, lebih mudah untuk melakukan pencucian media, tidak terlalu terpengaruh oleh tingkat kekeruhan air atau limbah baku. Sedangkan kelemahan dari media pasir sistem aliran up flow yaitu : lebih rumit karena memerlukan pengaturan tekanan khusus untuk bisa mengalirkan air atau limbah ke arah atas, kecepatan penyaringan media pasir rendah, sehingga memerlukan ruang yang cukup luas.

Laju pertumbuhan biologis pada biofilter sangat dipengaruhi oleh beberapa faktor, seperti tingkat fluktuasi kualitas limbah cair yang masuk (influent) yaitu $\mathrm{pH}$, temperatur dan waktu tinggal pada bagian bed (media), (Lemlit ITS -1998). Beberapa keunggulan proses pengolahan air limbah dengan biofilter antara lain adalah : pengolahannya sangat mudah, biaya operasinya rendah, dibandingkan dengan proses lumpur aktif, maka lumpur yang dihasilkan relatif sedikit, dapat menghilangkan nitrogen dan phosphor yang dapat menyebabkan euthropikasi, suplai udara untuk aerasi relatif kecil, dapat digunakan untuk air limbah dengan beban BOD yang cukup besar, dapat menghilangkan padatan tersuspensi (SS) dengan baik, (Wahyu Hidayat \& Nusa Idaman Said, 2005).

Tujuan dari penelitian ini adalah untuk mengetahui efisiensi penurunan kandungan TSS, $\mathrm{BOD}_{5}, \mathrm{COD}, \mathrm{PO}_{4}$ pada limbah cair IPAL Sentral RSUD Dr. Soetomo Surabaya dengan menggunakan reaktor biofilter yang membandingkan 3 buah reaktor. Reaktor pertama menggunakan media pasir silika dan gravel, reaktor kedua menggunakan media bioball dan reaktor ketiga menggunakan gabungan media pasir silika-gravel dan media bioball. Manfaat dari hasil penelitian ini adalah sebagai teknologi alternatif di dalam pengolahan limbah cair di RSUD Dr. Soetomo Surabaya.

Biological Oxygen Demand (BOD) adalah jumlah oksigen yang diperlukan oleh bakteri untuk mendekomposisi bahan organic hingga stabil pada kondisi aerobik, (Kumar dkk, 2010). Pemeriksaan BOD diperlukan untuk mentukan beban pencemar akibat air bungan dari rumah sakit atu indutri, (Sugito, 2009). Chemical Oxygen Demand (COD) adalah jumlah oksigen ( $\mathrm{mg} \mathrm{O}_{2}$ ) yang dibutuhkan untuk mengoksidasi zat-zat organik yang ada dalam 1 liter sample air, dimana 
pengoksidasi $\mathrm{K} 2 \mathrm{Cr} 2 \mathrm{O} 2$ di gunakan sebagai sumber oksigen, (Sugito, 2009). Angka COD merupakan ukuran pencemaran zat-zat ornaik yang secara alamiah dapat dioksidasi melalui proses mikrobiologi dan mengakibatkan berkurangnya oksigen terlarut di dalam air limbah, (Alaerts \& Santika, 1984). Untuk pemeriksaan COD berdasarkan SNI 06-6989.2-2004.Total Suspended Solid (TSS) adalah berat kering lumpur yang ada di dalam air limbah setelah mengalami penyaringan, (Sugiharto, 1987). Untuk pemeriksaan TSS berdasarkan SNI 06-6989.32004. Phospat (PO4) adalah senyawa yang dapat menyebabkan eutrofikasi dan mengurangi diversitas tumbuhan air. Pengukuran kandungan fosfat dalam air limbah berfungsi untuk mencegah tingginya kadar fosfat yang dapat mengurangi kadar oksigen terlarut, (Ayuningtyas, 2009)

\section{METODE PENELITIAN}

Penelitian ini merupakan penelitian eksperimen dengan uji laboratorium yang menggunakan reaktor biofilter untuk mengolah limbah cair dari IPAL sentral RSUD Dr. Soetomo yang akan direkayasa menyerupai kondisi dilapangan dan dibuat dalam bentuk mini. Desain penelitian yang gunakan yaitu limbah cair dari IPAL Sentral sebelum dikenakan perlakuan dilakukan pengukuran (Pre test/A1), kemudian diberikan perlakukan (Treatment/X) dengan menggunakan media biofilter berupa pasir silika dan kerikil serta media bioball, dan kemudian setelah dikenakan perlakukan dilaksanakan pengukuran lagi (Post test/B1). Pada posisi "Post tes/B1" dilakukan 5 kali pengukuran limbah cair yaitu pengukuran pertama dilakukan setelah limbah cair melewati media saringan pasir silika-kerikil dan penambahan oksigen dan yang ke dua dilakukan setelah melalui media bioball dan penambahan oksigen serta pengukuran yang ketiga dilakukan setelah limbah cair melewati media pasir silika - kerikil yang digabungkan dengan media bioball yang diberikan penambahan oksigen. Jumlah sample yang diambil pada lokasi pre test dan post test yaitu 5 kali pengambilan sample di posisi pre test, 5 kali pengambilan sample setelah media pasir silika kerikil (post test) dan penambahan oksigen, 5 kali pengambilan sample setelah media bio ball (post test) dan penambahan oksigen dan 5 kali pengambilan sample setelah melalui media pasir silika-kerikil dan media bioball (Post test) serta penambahan oksigen. Populasi dalam penelitian ini berupa limbah cair dari IPAL Sentral RSUD Dr. Soetomo Surabaya yang berasal dari berbagai unit pelayanan kesehatan di masing-masing ruangan. Sampel yang diteliti merupakan limbah cair yang berasal dari IPAL Sentral RSUD Dr. Soetomo Surabaya yang ditampung di tandon air ukuran masing-masing \pm 40 liter dan dialirkan secara kontinyu 24 jam dengan dibantu oleh submersible pump.

Alat dan bahan yang disiapkan yaitu 1 lonjor pipa PVC ukuran 5 inchi sepanjang $6 \mathrm{~m}$ di potong masing-masing sepanjang $150 \mathrm{~cm}$, sehingga sebanyak 4 buah potongan, dan bagian bawahnya ditutup dengan menggunakan dop pipa, setelah itu dilakukan pengeleman. Pada posisi inlet menuju ke media biofilter (pasir silika ukuran 2-5 mm dan krikil ukuran 2-3 cm) dihubungkan dengan pipa PVC ukuran 0,5 inchi sepanjang $50 \mathrm{~cm}$ yang dilengkapi dengan stopkran dan pada bagian bawah tabung di lengkapi dengan kran air ukuran 0,5 inci. Dari tabung biofilter (pasir silika dan kerikil) menuju ke tabung yang berisi media bio ball ukuran $4 \mathrm{~cm}$ dihubungkan dengan pipa PVC ukuran 0,5 inchi dengan posisi aliran air up flow dan dilengkapi dengan stop kran air ukuran 0,5 inchi, selain itu pada bagian bawah bio ball juga dilengkapi dengan kran air ukuran 0,5 inchi pada bagian bawah dibuatkan lubang untuk menginjek oksigen ke media bioball, untuk meningkatkan daya saring media di dalam reaktor terhadap limbah cair, maka di bagian bawah di lapisi dengan filter nylon. Dari tabung bioball kemudian di keluarkan melalui outlet yang telah di sediakan.

Adapun untuk gambar pengolahan limbah cair dengan reaktor biofilter disajikan pada gambar 1, gambar 2 dan gambar 3 di bawah ini.

a. Media Pasir Silika dan Krikil (Reaktor I) 


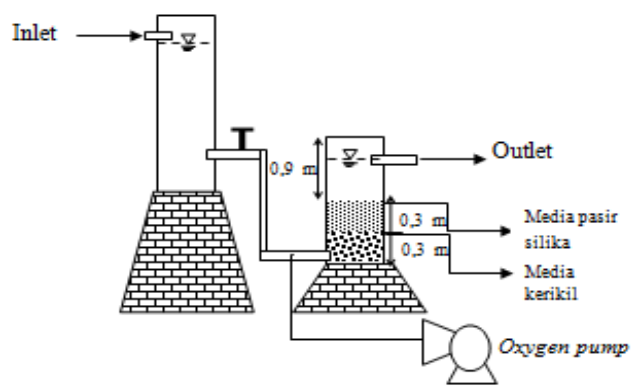

Gambar 1. Biofilter Media Pasir Silika dan Krikil

b. Media Bioball (Reaktor II)

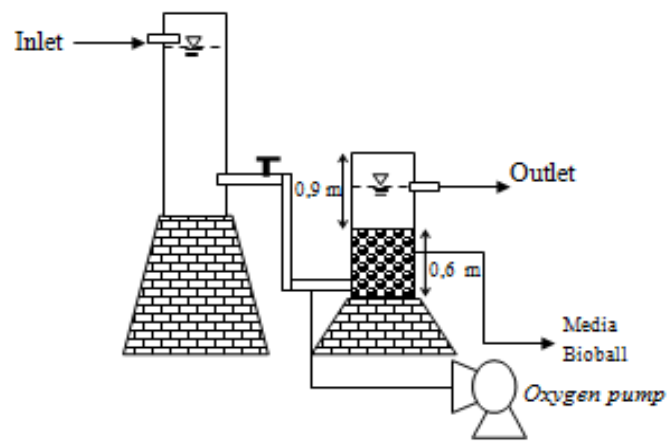

Gambar 2. Biofilter Media Bioball

c. Media Pasir Silika-Krikil dan Bioball (Reaktor III)

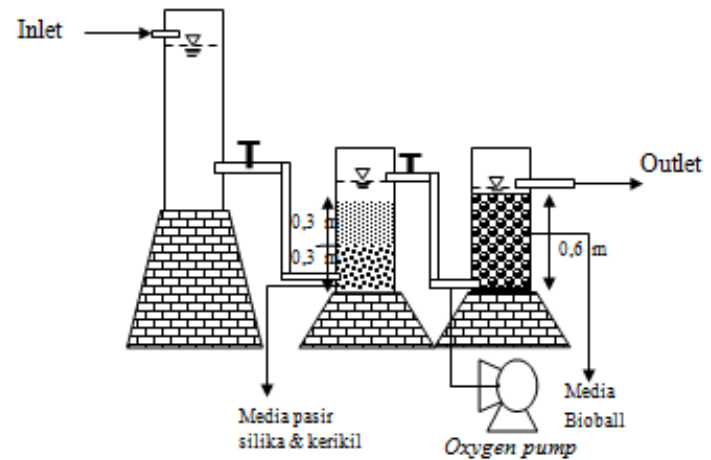

Gambar 3. Biofilter Media Pasir Silika-Krikil dan Bioball

Aktivasi untuk media reaktor biofilter dalam penelitian ini yaitu dengan menggunakan cara sebagai berikut : untukaktivasi biofilter dengan menggunakan media pasir silika dan kerikil dengan cara media tersebut di rendam di dalam bak bioreaktor IPAL Sentral RSUD Dr.Soetomo yang bertujuan untuk menumbuhkan bakteri atau mikroba yang dicirikan dengan timbulnya biofilm yang ada di permukaan pasir silika dan kerikil yang menunjukkan bahwa bakteri atau mikroba tersebut telah berada di dalam media. Sedangkan untuk aktivasi biofilter dengan menggunakan media bioball yaitu dengan cara media tersebut di rendam di dalam bak bioreaktor IPAL Sentral RSUD Dr. Soetomo yang bertujuan untuk menumbuhkan bakteri atau mikroba yang dicirikan dengan timbulnya biofilm dipermukaan media bioball.

Metode pengumpulan data dilakukan dengan cara antara lain observasi yaitu dengan melihat secara langsung ke lokasi penelitian dengan melakukan pengamatan yang menggunakan panca indra dan alat tulis sebagai alat untuk mencatat volume dan debit limbah cair dan pengambilan sample untuk uji laboratorium dan metode pengumpulan data yang lain yaitu dengan cara dokumentasi yaitu dengan mengumpulkan data sekunder dari hasil analisa laboratorium limbah cair IPAL Sentral dari RSUD Dr. Soetomo dan foto yang berhubungan dengan pengolahan limbah cair di lokasi RSUD Dr. Soetomo Surabaya. 
Adapun untuk data penelitian yang diambil meliputi : data primer berupa data yang diperoleh dari hasil pengambilan sample limbah cair sebelum dan sesudah proses pengolahan limbah cair dengan reaktor biofilter, data debit limbah, $\mathrm{pH}$ dan temperatur air limbah serta data sekunder berupa data laporan bulanan kualitas limbah cair di IPAL Sentral RSUD Dr. Soetomo dan data lain yang berhubungan dengan pengolahan limbah cair. Metode analisa data dihitung dengan membandingkan hasil uji sampel awal dengan hasil uji sampel akhir untuk mengetahui tingkat efisiensi penurunan $\mathrm{BOD}_{5}, \mathrm{COD}$, Phospat $\left(\mathrm{PO}_{4}\right)$ dan TSS dan baku mutu limbah cair rumah sakit berdasarkan Peraturan Gubernur Jawa Timur No. 72 Tahun 2013

\section{HASIL PENELITIAN}

Hasil analisa kualitas limbah cair sebelum dan sesudah pengolahan limbah cair dengan reaktor biofilter pada parameter TSS seperti di tunjukkan pada gambar 4 di bawah ini

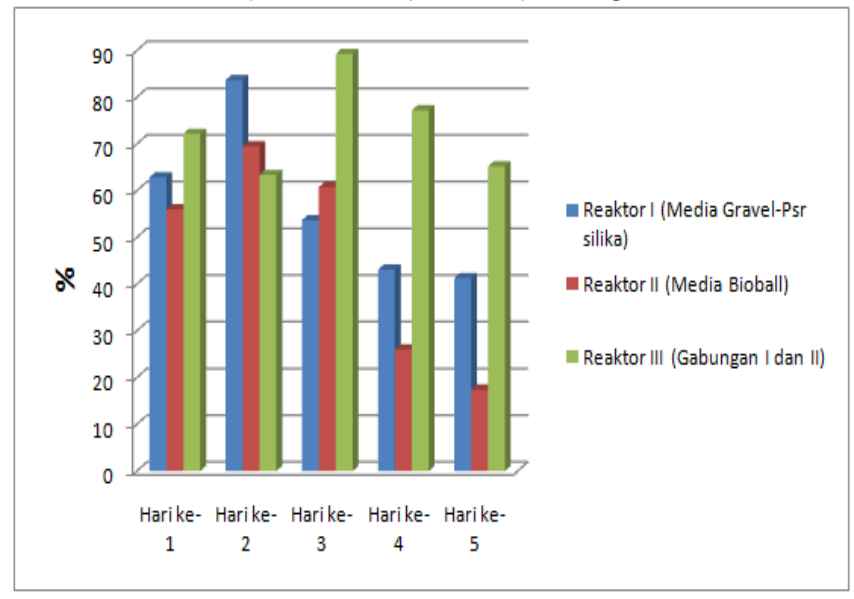

Gambar 4 Grafik Efisiensi Penurunan Kandungan TSS

Berdasarkan grafik pada gambar 4 di atas bahwa untuk efisiensi penurunan kandungan TSS pada reaktor ke-1 yaitu pada reaktor biofilter dengan media kerikil dan pasir silika berada diantara $41 \%$ sampai dengan $83 \%$ dengan rata - rata efisiensi penurunan $57 \%$, sedangkan pada reaktor ke-2 reaktor biofilter dengan media bioball efisiensi penurunan TSS berada di antara $17 \%$ sampai dengan $69 \%$ dengan rata - rata efisiensi penurunan $46 \%$, dan pada reaktor ke-3 reaktor biofilter dengan media gabungan media reaktor I dan media reaktor II efisiensi penurunan TSS berada di antara $63,4 \%$ sampai dengan $89,3 \%$ dengan rata - rata efisiensi penurunan $73 \%$. Untuk hasil analisa kualitas limbah cair sebelum dan sesudah pengolahan limbah cair dengan reaktor biofilter pada parameter BOD seperti di tunjukkan pada gambar 5 di bawah ini

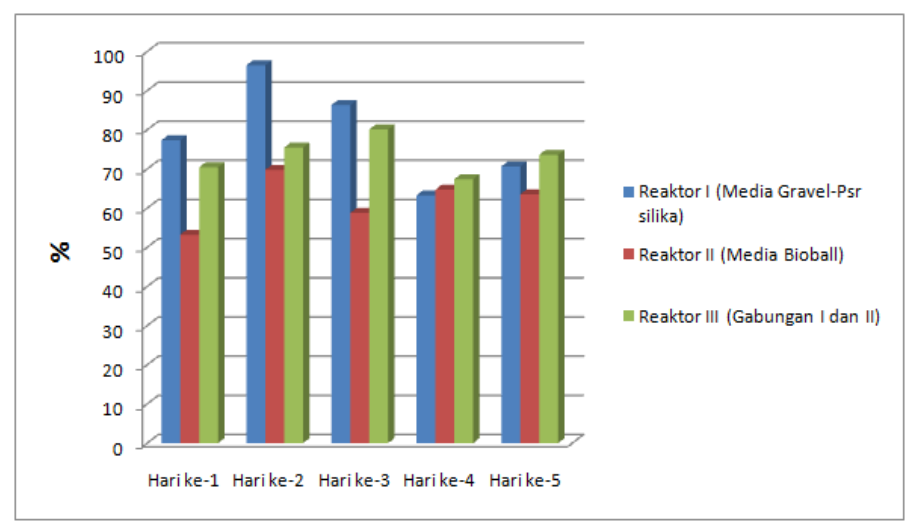

Gambar 5 Grafik Efisiensi Penurunan Kandungan $\mathrm{BOD}_{5}$

Berdasarkan grafik pada gambar 5 di atas bahwa untuk efisiensi penurunan kandungan $\mathrm{BOD}_{5}$ pada reaktor ke-1 yaitu pada reaktor biofilter dengan media kerikil dan pasir silika berada diantara $61,76 \%$ sampai dengan $78,76 \%$ dengan rata - rata efisiensi penurunan $71 \%$, 
sedangkan pada reaktor ke-2 reaktor biofilter dengan media bioball efisiensi penurunan $\mathrm{BOD}_{5}$ berada di antara 53\% sampai dengan $69 \%$ dengan rata - rata efisiensi penurunan $62 \%$, dan pada reaktor ke-3 reaktor biofilter dengan media gabungan media reaktor I dan reaktor II efisiensi penurunan $\mathrm{BOD}_{5}$ berada di antara $67, \%$ sampai dengan $80 \%$ dengan rata - rata efisiensi penurunan $73 \%$. Hasil analisa kualitas limbah cair sebelum dan sesudah pengolahan limbah cair pada parameter COD seperti di tunjukkan pada gambar 6 di bawah ini

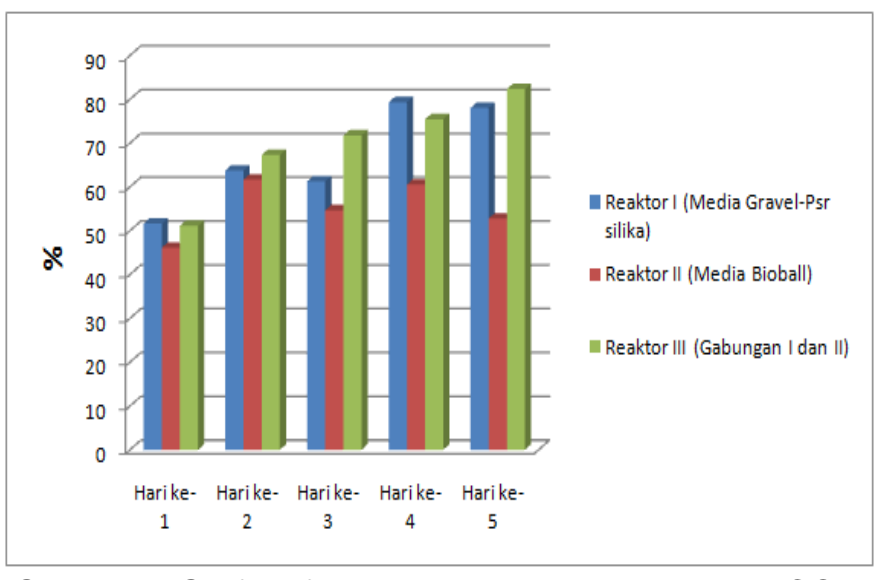

Gambar 6 Grafik Efisiensi Penurunan Kandungan COD

Berdasarkan grafik pada gambar 6 di atas bahwa untuk efisiensi penurunan kandungan COD pada reaktor ke-1 yaitu pada reaktor biofilter dengan media kerikil dan pasir silika berada diantara $51 \%$ sampai dengan $79 \%$ dengan rata - rata efisiensi penurunan $67 \%$, sedangkan pada reaktor ke-2 reaktor biofilter dengan media bioball efisiensi penurunan COD berada di antara $46 \%$ sampai dengan $61 \%$ dengan rata - rata efisiensi penurunan $55 \%$, dan pada reaktor ke-3 reaktor biofilter dengan media gabungan media reaktor I dan reaktor II efisiensi penurunan COD berada di antara $51 \%$ sampai dengan $82 \%$ dengan rata - rata efisiensi penurunan $70 \%$ Adapun untuk hasil analisa kualitas limbah cair sebelum dan sesudah pengolahan limbah cair pada parameter $\mathrm{PO}_{4}$ seperti di tunjukkan pada gambar 7 di bawah ini

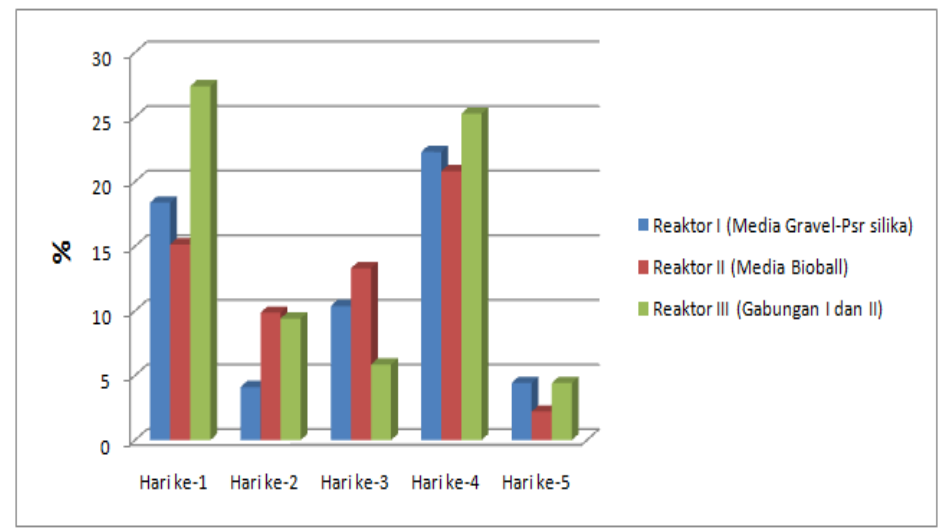

Gambar 7 Grafik Efisiensi Penurunan Kandungan $\mathrm{PO}_{4}$

Berdasarkan grafik pada gambar 7 di atas bahwa untuk efisiensi penurunan kandungan $\mathrm{PO}_{4}$ pada reaktor ke-1 yaitu pada reaktor biofilter dengan media gravel dan pasir silica berada diantara $4 \%$ sampai dengan $22 \%$ dengan rata - rata efisiensi penurunan $12 \%$, sedangkan pada reaktor ke-2 reaktor biofilter dengan media bioball efisiensi penurunan $\mathrm{PO}_{4}$ berada di antara $2 \%$ sampai dengan $20 \%$ dengan rata - rata efisiensi penurunan $13 \%$, dan pada reaktor ke-3 reaktor biofilter dengan media gabungan media reaktor I dan reaktor II efisiensi penurunan $\mathrm{PO}_{4}$ berada di antara $4 \%$ sampai dengan $27 \%$ dengan rata - rata efisiensi penurunan $14 \%$ 


\section{PEMBAHASAN}

Berdasarkan hasil penelitian menunjukkan bahwa telah terjadi penurunan kandungan TSS, BOD, COD dan Phospat $\left(\mathrm{PO}_{4}\right)$ dalam sistem pengolahan limbah cair dengan teknologi biofilter yang menggunakan media gravel-pasir silika, media bioball dan gabungan media gravel-pasir silika dan media bioball. Hasil penelitian menunjukkan bahwa pada reaktor dengan media krikilpasir silika, untuk kandungan TSS terjadi penurunan rata - rata $24 \mathrm{mg} / \mathrm{l}$ dengan efisiensi penurunan rata - rata $57 \%$, untuk reaktor biofilter dengan media bioball terjadi penurunan kandungan TSS rata- rata $22 \mathrm{mg} / \mathrm{l}$ dengan efisiensi penurunan rata - rata $46 \%$. Adapun untuk reaktor biofilter dengan menggunakan gabungan media krikil-pasir silika dan media bioball terjadi penurunan kandungan TSS rata- rata $34 \mathrm{mg} / \mathrm{l}$ dengan efisiensi penurunan rata - rata $73 \%$. Untuk kandungan $\mathrm{BOD}_{5}$ pada reaktor dengan media krikil-pasir silika, terjadi penurunan rata rata $78 \mathrm{mg} / \mathrm{l}$ dengan efisiensi penurunan rata - rata $71 \%$, untuk reaktor biofilter dengan media bioball terjadi penurunan kandungan $\mathrm{BOD}_{5}$ rata- rata $68 \mathrm{mg} / \mathrm{l}$ dengan efisiensi penurunan rata rata $62 \%$. Adapun untuk reaktor biofilter dengan menggunakan gabungan media kerikill-pasir silika dan media bioball terjadi penurunan kandungan $\mathrm{BOD}_{5}$ rata- rata $81 \mathrm{mg} / \mathrm{l}$ dengan efisiensi penurunan rata - rata $73 \%$. Untuk kandungan COD pada reaktor dengan media kerikil-pasir silika, terjadi penurunan rata - rata $144 \mathrm{mg} / \mathrm{l}$ dengan efisiensi penurunan rata - rata $67 \%$, untuk reaktor biofilter dengan media bioball terjadi penurunan kandungan COD rata- rata $123 \mathrm{mg} / \mathrm{l}$ dengan efisiensi penurunan rata - rata $55 \%$. Adapun untuk reaktor biofilter dengan menggunakan gabungan media kerikil-pasir silika dan media bioball terjadi penurunan kandungan COD rata- rata $152 \mathrm{mg} / \mathrm{l}$ dengan efisiensi penurunan rata - rata $69 \%$.

Adapun untuk kandungan $\mathrm{PO}_{4}$ pada reaktor dengan media kerikill-pasir silika, terjadi penurunan rata - rata $0,91 \mathrm{mg} / \mathrm{l}$ dengan efisiensi penurunan rata - rata $12 \%$, untuk reaktor biofilter dengan media bioball terjadi penurunan kandungan $\mathrm{PO}_{4}$ rata- rata $0,29 \mathrm{mg} / \mathrm{l}$ dengan efisiensi penurunan rata - rata $12 \%$. Adapun untuk reaktor biofilter dengan menggunakan gabungan media gravel-pasir silica dan media bioball terjadi penurunan kandungan $\mathrm{PO}_{4}$ rata- rata 0,348 $\mathrm{mg} / \mathrm{l}$ dengan efisiensi penurunan rata - rata $14 \%$.

Pada ketiga reaktor biofilter yang diteliti telah menunjukkan penurunan kandungan TSS, $\mathrm{BOD}, \mathrm{COD}$ dan Phospat $\left(\mathrm{PO}_{4}\right)$. Namun pada reaktor yang berisi gabungan media pasir silikakerikil dan media bioball efisiensi penurunan kandungan semua parameter yang diteliti lebih tinggi dibandingkan dengan reaktor dengan media kerikil- pasir silika dan media bioball saja. Hal ini disebabkan karena limbah cair yang dilakukan pengolahan pada reaktor pertama telah menunjukkan proses penurunan kandungan TSS, $\mathrm{COD}, \mathrm{BOD}_{5}$ dan $\mathrm{PO} 4$ dan jika dilanjutkan dengan reaktor kedua, maka efisiensi proses pengolahannya akan menjadi lebih tinggi lagi. Hal ini sejalan dengan penelitian yang dilakukan oleh Wahyu Hidayat \& Nusa Idaman Said (2005) dan penelitian yang dilakukan oleh Sugito (2009) bahwa pengolahan limbah cair rumah sakit dengan menggunakan reaktor biofilter anaerobic-aerobik dapat menurunkan kandungan TSS, COD, BOD5, dan Phospat (PO4).

\section{SIMPULAN DAN SARAN}

Berdasarkan hasil penelitian yang telah dilakukan yaitu dengan menggunakan 3 buah reaktor biofilter yang menggunakan media berbeda dengan debit limbah cair yang kontinyu dan waktu tinggal lebih dari 5 jam, maka dapat disimpulkan sebagai berikut :

1. Reaktor biofilter dengan media pasir silica-kerikill mampu menurunkan kandungan TSS ratarata $57 \%$, menurunkan kandungan $\mathrm{BOD}_{5}$ rata - rata $71 \%$, menurunkan kandungan $\mathrm{COD}$ rata rata $67 \%$ dan menurunkan kandungan Phospat $\left(\mathrm{PO}_{4}\right)$ rata - rata $12 \%$.

2. Reaktor biofilter dengan media bioball mampu menurunkan kandungan TSS rata-rata $46 \%$, menurunkan kandungan $\mathrm{BOD}_{5}$ rata - rata $62 \%$, menurunkan kandungan $\mathrm{COD}$ rata - rata $55 \%$ dan menurunkan kandungan Phospat $\left(\mathrm{PO}_{4}\right)$ rata - rata $12 \%$.

3. Reaktor biofilter dengan media gabungan yaitu media pasir silica-kerikil dengan media bioball mampu menurunkan kandungan TSS rata-rata 73,46 , menurunkan kandungan $\mathrm{BOD}_{5}$ rata rata $73,40 \%$ dan menurunkan kandungan COD rata - rata $69 \%$.

Berdasarkan hasil penelitian didapatkan bahwa reaktor biofilter sangat efektif di dalam menurunkan kandungan pencemar seperti TSS, BOD, $\mathrm{COD}$, dan Phospat $\left(\mathrm{PO}_{4}\right)$ namun disarankan beberapa hal sebagai berikut :

1. Untuk memperoleh hasil pengolahan limbah cair yang lebih baik pada reaktor biofilter yang menggunakan media pasir silika-kerikill, maka perlu dilakukan penelitian terkait dengan ukuran dan ketebalan media yang efektif untuk mengolah limbah cair rumah sakit 
2. Perlu dilakukan penelitian terkait dengan ukuran dan ketebalan media bioball yang efektif digunakan untuk mengolah limbah cair rumah sakit dengan menggunakan reactor biofilter

3. Perlu dilakukan penelitian terkait dengan jenis media lain yang efektif digunakan sebagai media pada reactor biofilter di dalam melakukan pengolahan limbah cair rumah sakit .

\section{DAFTAR PUSTAKA}

Alaerts G., dan Santika, S.S. 1984, Metode Penelitian Air, Surabaya : Penerbit Usaha Nasional.

Ayuningtyas, R.D. 2009, Proses Pengolahan Limbah cair RSUD Dr. Moewardi Surakarta, Surakarta : Universitas Sebelas Maret

Keputusan Gubernur Provinsi Jawa Timur No. 72 Tahun 2013 tentang Baku Mutu Limbah Cair bagi Kegiatan Rumah Sakit di Provinsi Jawa Timur.

Komariah, S. dan Sugito, 2011. "Perencanaan Biofilter di UPTD Kesehatan Puskesmas Gondang wetan Kabupaten Pasuruan". Jurnal Teknik Waktu, ISSN:1412-1867 volume 11 Nomor 01 Januari 2012

Kumar , A., Purnima, D., dan rita, K, 2010."Redefining BOD : COD Ratio of pulp Mill Industrial Wastewaters in BOD Analysis by Formulating a Specific Microbial seed" Journal of International Biodeterioration and Biodegradation. Vol. 64 : 197-202

Lemlit ITS Surabaya, 1998, "Pengolahan Limbah Cair Klinik Semen Gresik di Tuban", Penelitian Limbah cair Klinik Semen Gresik Tuban.

Maharani, Lydya, 2005. "Evaluasi dan Pengembangan Instalasi Pengolahan Air Limbah RSUD Dr. Soetomo Surabaya". Laporan tugas akhir. Jurusan Teknik Lingkungan, FTSP ITS Surabaya

Mara, D. 1978. Sewage Treatment in hot Climate. A wiley Interscience Publication, Chichester. USA

Metcalf \& Eddy, 1991 " Wastewater Engineering : Treatment, Disposal and Reuse "Third Edition. Mc Graw Hill, Inc.New York

Sugito, 2005."Aplikasi Instalasi Pengolahan Air Limbah Biofilter untuk Menurunkan Kandungan Pencemar BOD, COD dan TSS di Rumah sakit Bunda Surabaya". Surabaya, Program Studi Teknik Lingkungan Universitas PGRI Adi Buana Surabaya

Said, Nusa Idaman, 2005. "Aplikasi Bioball Untuk Media Biofilter Studi Kasus Pengolahan Air Limbah Pencucian Jean", Pusat pengkajian dan Penerapan Teknologi Lingkungan-BPPT.

Sugiharto (1987), Dasar-Dasar Pengolahan Air Limbah, Penerbit Universitas Indonesia, Jakarta Undang-Undang Republik Indonesia No. 44 Tahun 2009 tentang Rumah Sakit

Widayat, Wahyu \& Said, Nusa Idaman. "Rancang Bangun Paket IPAL Rumah Sakit Dengan Proses Biofilter An Aerobik-Aerob", Jakarta, Kelompok Teknologi Pengelolaan Air Bersih dan Limbah Cair Pusat Pengkajian dan Penerapan Teknologi Lingkungan, BPPT. 